\title{
COMPOSITION AND DISTRIBUTION OF PHOSPHORUS FORMS IN SEDIMENTS OF GREENFIELD LAKE, WILMINGTON, NORTH CAROLINA
}

\author{
MARISSA D. ROMAN AND LAWRENCE B. CAHOON ${ }^{1}$ \\ Dept. of Biology and Marine Biology \\ University of North Carolina Wilmington \\ Wilmington, N.C. 28403-5915 \\ E-mail:mdroman831@gmail.com \\ ${ }^{1}$ Corresponding author: Cahoon@uncw.edu
}

\begin{abstract}
Greenfield Lake in Wilmington, NC, has experienced recent problems with algal blooms, low dissolved oxygen levels, and fish kills, although various remedial actions have been taken that led to some visible improvements over the last decade. Many of these issues have likely been caused by high nutrient loading from the lake's urbanized watershed. The role of lake sediment as a source and a sink for phosphorus (P), which is often considered the nutrient most responsible for freshwater eutrophication, has not been examined. We identified and quantified the forms of $\mathrm{P}$ in the lake's sediments. Fourteen sites were sampled around the lake in 2012-2013. A sequential extraction procedure allowed analysis of five $\mathrm{P}$ forms of varying bioavailability. Total $\mathrm{P}$ concentrations in the sediment averaged $51.1 \mu \mathrm{g} \mathrm{g}^{-1}$ sediment, which is low relative to other lakes. The most concentrated $\mathrm{P}$ forms were the reductant-extractable, acid-extractable and residual $\mathrm{P}$ fractions. These results, and very low concentrations of more readily bioavailable $\mathrm{P}$ fractions, strongly indicate that the lake's abundant plant biota (phytoplankton, filamentous algae, and macrophytes) control and sequester most of the $\mathrm{P}$ load in the lake's water column. Further remediation efforts should consider the role of these plant populations in regulating the lake's water quality.
\end{abstract}

Key Words: Phosphate; Sediment; Fractionation; Greenfield Lake.

\section{INTRODUCTION}

Lake eutrophication is a serious environmental problem in the United States. Excess nutrients that enter aquatic ecosystems through discharges from industry, agriculture, and development can result in algal blooms and fish kills, which signal a decline in the overall water quality of a body of water. Phosphorus (P) has been recognized as the primary limiting nutrient in lake ecosystems (Hecky and Kilham 1988) and, therefore, can support eutrophication when available. Phosphorus can come from both point and nonpoint sources, but nonpoint sources are often more significant contributors, particularly in urbanized and agricultural watersheds.

The concentration of bioavailable $\mathrm{P}$ in a body of water is non-conservative and is influenced by many factors. Biological and chemical processes occurring within lakes can drive intense cycling of phosphorus. Many of these processes occur near or within the sediment-water interface. Therefore, sediments can play an important role in $\mathrm{P}$ exchange and cycling, and can act as important sinks and sources of this nutrient. For example, soils of flooded restoration wetlands constructed on agricultural lands near Upper Klamath Lake, Oregon, released approximately 64 tons of $\mathrm{P}$ over
3,000 ha $\left(=2.13 \mathrm{~g} \mathrm{~m}^{-2}\right)$ during the course of one study (Aldous et al. 2007). Similarly, Spears et al. (2007) found that the main source of $\mathrm{P}$ to the water column of a large shallow lake (Loch Leven, Scotland) was from the sediment through microbial remineralization. In that study, increases in water column soluble reactive phosphorus (SRP) correlated with decreasing sediment phosphorus, indicating $\mathrm{P}$ was released from the sediment.

Direct measures of $\mathrm{P}$ fluxes from aquatic sediments have also shown substantial $\mathrm{P}$ releases, depending on conditions (Søndergaard et al. 2013; Zhang et al. 2013). Lake sediment may therefore act as a reservoir for high concentrations of $\mathrm{P}$ because of its capacity to store $\mathrm{P}$ in various forms, but can then become a major source of $\mathrm{P}$ to overlying waters under specific conditions. Efforts are often initiated to reduce external nutrient loading into water bodies when there are high concentrations of $\mathrm{P}$ in the sediment and water column. However, several studies have shown that reductions in external phosphorus loading have actually resulted in increases in internal phosphorus loading (Sondergaard et al. 1993; Sondergaard et al. 2003). In these circumstances, high concentrations of sediment $\mathrm{P}$ were released from the sediment in response to decreasing concentrations in the water column. The sediment in these cases acted as an 
active reservoir to maintain the concentration of $\mathrm{P}$ in the water; it is likely that this would occur for forms of $\mathrm{P}$ that are in water/sediment equilibrium via adsorption/ desorption processes and not for more biologically and chemically refractory $\mathrm{P}$ forms. Overall, however, the ability of the sediment to act as a $\mathrm{P}$ source can undermine remediation efforts because of internal loading of available sediment-associated $\mathrm{P}$ forms.

Not all forms of sediment phosphorus are biologically available or easily released from lake sediment. To be able to differentiate different forms of $\mathrm{P}$ present in lake sediment, sequential fractionation schemes have been developed in order to quantify the concentrations of various types of sediment P, e.g., Psenner et al. (1984). This analytical approach is based on the solubility of different fractions in various extractant solutions. While sequential $\mathrm{P}$ extractions yield operationally-defined fractions, these fractions do not necessarily correspond to specific P compounds (Pettersson et al. 1988), nor is it easy to use sequential extraction schemes to identify specific sources of sediment $\mathrm{P}$, as chemical and biological processes in sediments, water and biota transform $\mathrm{P}$ readily. Nonetheless, the identification of the forms of phosphorus present in the sediment can indicate what chemical reactions or biological transformations may be occurring in situ. This information can be used to evaluate the $\mathrm{P}$ exchange process and to better understand $\mathrm{P}$ cycling.

Greenfield Lake is a shallow (mean depth 2-3 m), blackwater, eutrophic lake located in downtown Wilmington, North Carolina. It drains a watershed of 2,551 acres (1,032 ha), with a population of approximately 10,630 (Mallin et al. 2012), and it empties into the nearby Cape Fear River Estuary. It was formed in the 1730 s by damming a naturally occurring stream and wetland. Greenfield Lake has had many water quality problems in the past with algal blooms, low dissolved oxygen levels, and fish kills (Mallin et al. 2013). Several methods have been implemented by the City of Wilmington in the last decade in an effort to restore this aquatic ecosystem (Mallin et al. 2013). The City has constructed stormwater detention ponds in the main tributaries feeding the lake to control nutrient and other loadings from its highly urbanized watershed $36 \%$ impervious cover). Sterile grass carp have been introduced into the lake to control macrophytes by grazing, which has, thus far, visibly reduced macrophyte plant populations somewhat. Four SolarBee water circulation systems have also been placed in the lake to mix the water, distribute dissolved oxygen downwards, and decrease soluble $\mathrm{P}$ that would otherwise be available to algae. Several herbicide applications have been used to further reduce plant growth. Finally, the City of Wilmington contracted in the early 2000s for suction dredging to remove accumulated muck and fine sediments to lower sediment-associated biochemical oxygen demand (BOD; C. O'Keefe, pers. comm.). These efforts, aimed at decreasing algal biomass and evenly distributing DO around the lake, have yielded some improvements in the water quality of the lake over the past few years, but extensive blooms of phytoplankton, filamentous algae and macrophytes, issues with low dissolved oxygen, and high fecal coliform bacteria concentrations persist (Mallin et al. 2012, 2013), and the lake remains in a eutrophic state.

Lake sediment can play an important role in $\mathrm{P}$ cycling, release, and availability in concert with variations in $\mathrm{P}$ inputs, dissolved oxygen, and plant uptake, but the role that the sediment plays in the P cycle within Greenfield Lake has not been investigated. We quantified the forms of sediment $\mathrm{P}$ present in Greenfield Lake in order to determine the potential bioavailability of sediment $\mathrm{P}$ for the lake's biota and thereby assess the impact that remediation efforts may have on internal P loading.

\section{METHODS}

\author{
Study Site
}

Samples were collected from Greenfield Lake in Wilmington, North Carolina USA $\left(34^{\circ} 12^{\prime} \mathrm{N},-77^{\circ} 56^{\prime} \mathrm{W}\right)$. Fourteen sites around the lake were sampled to ensure representative coverage of the lake and its main inflows (Fig. 1). Samples were collected from the shore in September 2012 (sites \#3-6) and by boat in October 2012 (sites \#1-2; \#7-11) and January 2013 (sites \#12-14) (Fig. 1). GPS coordinates of each location were identified and recorded using a Garmin Forerunner 405 GPS unit (Table 1).

\section{Sample Collection}

Sediment samples were collected using a coring device of adjustable length, depending on the depth of water in which the sample was to be taken. The coring device consisted of a wood rod attached to a rubber \#5 stopper and an $8.5 \mathrm{~cm}$ long, $2.3 \mathrm{~cm}$ diam (ID) plastic corer, both supported by a $1.9 \mathrm{~cm}$ diameter PVC pipe of corresponding overall length (Fig. 2). Two cores, taken to a depth of $8.5 \mathrm{~cm}$ in the sediment, were obtained at each sampling site. Cores were transferred to acid-washed $50 \mathrm{~mL}$ polypropylene centrifuge tubes and immediately returned to the lab, where they were dried at $70^{\circ} \mathrm{C}$ for at least 7 days, or until completely dry. Samples were then homogenized and a $1.5 \mathrm{~g}$ subsample was removed for sequential $\mathrm{P}$ extractions and analyses. The characteristics of the sediment at each site were described based on visual observations and are reported in Table 1.

\section{Phosphorus Extraction and Analysis}

A sequential phosphorus extraction scheme adapted from Psenner et al. (1984) and modified by Hupfer et al. 


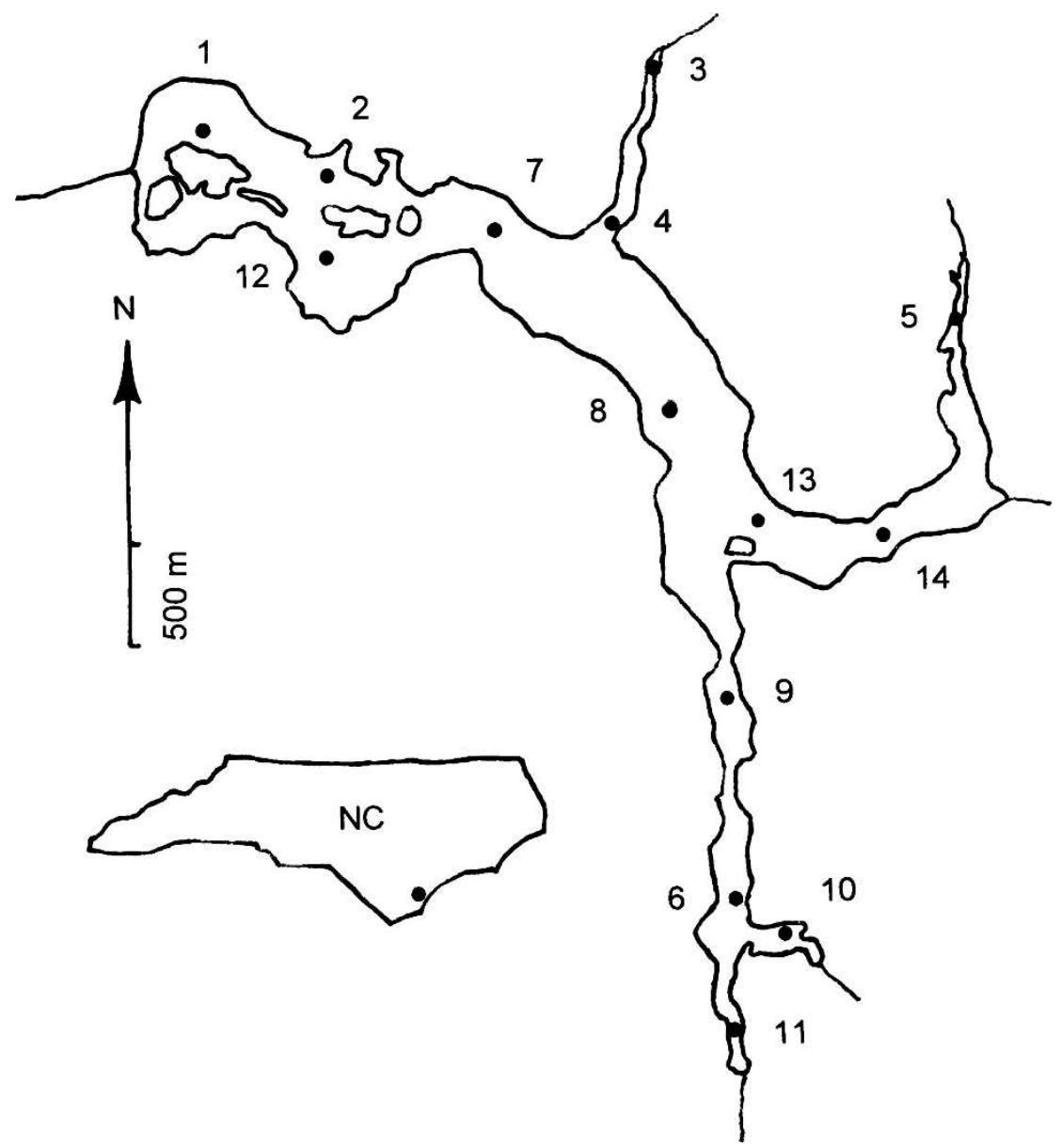

FIG. 1. Map of sampling site locations in Greenfield Lake within city of Wilmington corporate limits. Lake outlet flows west to the Cape Fear River Estuary.

(2009) was followed to extract the various forms of $\mathrm{P}$ from the dried lake sediment. Table 2 presents the extraction treatments and sequence. After each extraction step, sample mixtures were centrifuged and supernatants were removed as completely as possible. Then they were filtered, digested with a persulfate solution prepared according to Valderrama (1981), and analyzed for soluble reactive $\mathrm{P}$ (SRP) using the molybdenum-blue method (Parsons et al. 1984), with two exceptions: 1) the NaOH-P extract was digested with sulfuric acid, as persulfate digestion proved inadequate to remove completely all coloring substances (humic materials) that extracted in basic solution; SRP was then determined directly, following Hupfer et al.

Table 1. GPS coordinates and sediment descriptions of Greenfield Lake sampling sites.

\begin{tabular}{clll}
\hline Site \# & Lat. $(\mathrm{N})$ & Long. $(\mathrm{W})$ & Sediment Description \\
\hline 1 & 34.21292 & 77.94373 & Very fine, silty, dark brown \\
2 & 34.2121 & 77.94087 & Very fine, silty, dark brown \\
3 & 34.21423 & 77.93563 & Fine, sandy, light colored/tan \\
4 & 34.21137 & 77.9365 & Fine, sandy, light colored/tan \\
5 & 34.21133 & 77.93137 & Fine, sandy, light colored/tan \\
6 & 34.20203 & 77.93443 & Coarse, silty, dark brown \\
7 & 34.21128 & 77.93892 & Very fine, silty, dark brown \\
8 & 34.20897 & 77.93575 & Very fine, silty, dark brown \\
9 & 34.2046 & 77.9347 & Very fine, silty, dark brown \\
10 & 34.20145 & 77.93425 & Very fine, silty, dark brown \\
11 & 34.19938 & 77.93535 & Very fine, silty, dark brown \\
12 & 34.21098 & 77.94142 & Very fine, silty, dark brown \\
13 & 34.20717 & 77.93412 & Very fine, silty, dark brown \\
14 & 34.20712 & 77.93227 & Very fine, silty, dark brown \\
\hline
\end{tabular}


Corer

$17 \mathrm{~cm}$

$$
0.9 \mathrm{~m}, 1.8 \mathrm{~m} \text {, or } 2.4 \mathrm{~m} \text { long }
$$

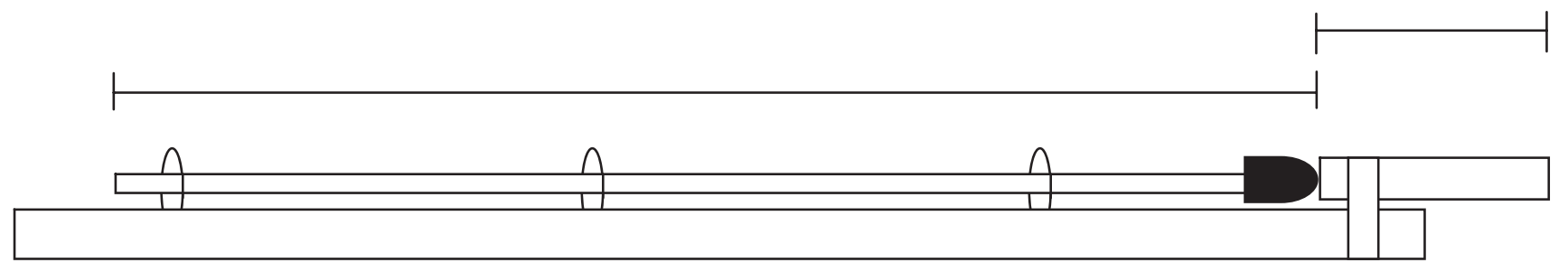

FIG. 2. Visual diagram of coring device, depicted horizontally. The wood rod is attached through guides to the black rubber stopper. This device is affixed to the PVC pipe. The $17 \mathrm{~cm}$ plastic corer $(2.3 \mathrm{~cm}$ diameter) that penetrates the sediment is on the right of the diagram. Overall length can be adjusted to water depth.

(2009); 2) residual $\mathrm{P}$ samples were digested with $5 \mathrm{M}$ sulfuric acid and then neutralized with sodium bicarbonate; SRP in the resulting supernatant was determined by the molybdenum-blue method. The molybdenum-blue mixed reagent was made up of $20 \% 0.03 \mathrm{M}$ ammonium molybdate, $50 \% 2.5 \mathrm{M}$ sulfuric acid solution, $20 \% 0.3 \mathrm{M}$ ascorbic acid, and 10\% $0.002 \mathrm{M}$ potassium antimonyl tartrate. One $\mathrm{ml}$ of mixed reagent was added to each $10 \mathrm{ml}$ sample aliquot, which then changed color to various shades of blue, depending on how much phosphorus was present. Absorbance of the solutions was read in a Thermo Spectronic Genesys 20 Visible Spectrophotometer at $885 \mathrm{~nm}$ against a suitable blank. The absorbance was converted to $\mu \mathrm{g} \mathrm{P} \mathrm{g}^{-1}$ sediment, using the following equation:

$$
\begin{aligned}
\mu \mathrm{P} \mathrm{g}^{-1} \text { sediment }= & \left(\mathrm{Abs}_{885}-\mathrm{Blank}_{885}\right) \\
& \times \mathrm{F} \times \text { Dilution factor } \times \mathrm{M} \div \mathrm{m}
\end{aligned}
$$

where $\mathrm{F}$ is a standardization factor that converts blankcorrected absorbance into $\mu \mathrm{M}$ P. The dilution factor corrects for addition of persulfate or other digestion reagents to samples and for sample volume (L). M is the molar mass of phosphorus (31), and $\mathrm{m}$ is the mass ( $\mathrm{g}$ ) of the dried sediment sample extracted.

Several additional experiments investigated the nature of the interference by humic materials with $\mathrm{P}$ analyses. Laboratory experiments using a solution of commer-

Table 2. Sequential phosphorus extraction scheme, as described by

\begin{tabular}{|c|c|}
\hline Fraction & Expected P Forms \\
\hline $1 \mathrm{M} \mathrm{NH}_{4} \mathrm{Cl}$ & $\mathrm{P}$ in pore water; $\mathrm{P}$ adsorbed loosely to surfaces \\
\hline $0.11 \mathrm{M}$ BD & Redox-sensitive $\mathrm{P}$ bound to oxidized $\mathrm{Fe} \& \mathrm{Mn}$ compounds \\
\hline $1 \mathrm{M} \mathrm{NaOH}$ & $\begin{array}{l}\mathrm{P} \text { sorbed on } \mathrm{Al} \text { and } \mathrm{Fe} \text { hydroxides; inorganic compounds } \\
\text { soluble in bases; } \mathrm{P} \text { in microorganisms; organic } \mathrm{P} \text { in } \\
\text { detritus; } \mathrm{P} \text { in humic compounds }\end{array}$ \\
\hline $0.5 \mathrm{M} \mathrm{HCl}$ & Ca phosphate minerals; acid-soluble organic $\mathrm{P}$ \\
\hline Residual & Refractory organic $\mathrm{P}$; non-extractable mineral $\mathrm{P}$ \\
\hline
\end{tabular}
Hupfer et al. (2009). Table describes each extracting solution utilized and the expected phosphorus species to be extracted from each. cially available humic acids (Fluka \#53680, $0.128 \mathrm{~g}$ dissolved in $0.01 \mathrm{M} \mathrm{NaOH}$ and filtered through glass fiber filters) were conducted to evaluate potential interference with measurement of SRP at $885 \mathrm{~nm}$ in undigested samples, efficiency of digestion of humic materials by persulfate treatment, measured as change in absorbance at $490 \mathrm{~nm}$, and $\mathrm{P}$ content of humic materials.

\section{RESULTS}

Total $\mathrm{P}$ was calculated as the sum of all five sequentially extracted and analyzed $\mathrm{P}$ fractions, and averaged $51.1 \mu \mathrm{g} \mathrm{P} \mathrm{g}^{-1}$ sediment, with a range of 22.0 to $80.0 \mu \mathrm{g} \mathrm{P} \mathrm{g}^{-1}$ sediment (Table 3). Although the lowest total $\mathrm{P}$ value came from a sandy sample and the highest from a finer-grained sediment, there was no apparent pattern of total $\mathrm{P}$ values compared to sediment descriptions in Table 1. Similarly there was no demonstrable spatial pattern of total $\mathrm{P}$ values among these sample locations (Fig. 1).

Analysis of the first extract in the sequence, dissolved or loosely adsorbed $\mathrm{NH}_{4} \mathrm{Cl}$-extractable $\mathrm{P}$, yielded very low values, averaging $2.43 \mu \mathrm{g} \mathrm{P} \mathrm{g}^{-1}$ sediment, with a range of 0.73 to $4.85 \mu \mathrm{g} \mathrm{P} \mathrm{g}^{-1}$ sediment (Table 3). No sediment-associated or spatial pattern was evident.

$\mathrm{P}$ content of the next fraction in the sequence, bicarbonate-dithionite (BD) extractable P (solubilized under reducing conditions), was significantly higher than in the first fraction, averaging $18.1 \mu \mathrm{g} \mathrm{P} \mathrm{g}$ sediment, with a range of 10.6 to $25.3 \mu \mathrm{g} \mathrm{P} \mathrm{g}^{-1}$ sediment (Table 3 ). The relatively small variability in these values among sites revealed no obvious association with sediment character or location.

The next fraction in the sequence, $\mathrm{NaOH}$-extractable $\mathrm{P}$, exhibited very low values across sample locations, averaging $5.38 \mu \mathrm{g} \mathrm{P} \mathrm{g}^{-1}$ sediment, with a range of 1.94 to 11.1 $\mu \mathrm{g} \mathrm{P} \mathrm{g}^{-1}$ sediment (Table 3); these data are for extracts digested with sulfuric acid. Although there was no clear pattern among the values for this fraction, it should be 
Table 3. Sediment $\mathbf{P}$ fractions from Greenfield Lake, ug $\mathrm{P}$ (g sediment $)^{-1}$.

\begin{tabular}{|c|c|c|c|c|c|c|}
\hline Site \# & $\mathrm{NH}_{4} \mathrm{Cl}-\mathrm{P}$ & BD-P & $\mathrm{NaOH}-\mathrm{P}$ & HCl-P & Res. P & $\Sigma \mathrm{P}_{-}$ \\
\hline 1 & 0.73 & 16.4 & 6.72 & 14.1 & 25.0 & 62.9 \\
\hline 2 & 1.94 & 15.3 & 6.68 & 13.1 & 22.3 & 59.4 \\
\hline 3 & 1.67 & 10.6 & 2.49 & 3.50 & 52.9 & 71.1 \\
\hline 4 & 4.16 & 25.3 & 1.94 & 12.5 & 0.26 & 44.2 \\
\hline 5 & 2.40 & 11.8 & 4.03 & 3.06 & 0.70 & 22.0 \\
\hline 6 & 3.52 & 17.2 & 2.65 & 4.28 & 0.61 & 28.3 \\
\hline 7 & 4.85 & 23.2 & 4.07 & 30.3 & 0.43 & 62.8 \\
\hline 8 & 2.19 & 15.6 & 4.39 & 25.3 & 14.9 & 62.3 \\
\hline 9 & 2.56 & 19.2 & 5.40 & 19.4 & 18.8 & 65.4 \\
\hline 10 & 3.29 & 22.3 & 6.31 & 24.0 & 0.80 & 56.7 \\
\hline 11 & 1.28 & 20.1 & 6.47 & 36.1 & 16.1 & 80.0 \\
\hline 12 & 2.42 & 18.2 & 5.15 & 4.03 & 0.05 & 29.8 \\
\hline 13 & 0.94 & 20.4 & 11.1 & 1.39 & 0.10 & 33.9 \\
\hline 14 & 2.06 & 17.9 & 7.91 & 1.24 & 6.95 & 36.1 \\
\hline Mean & 2.43 & 18.1 & 5.38 & 13.7 & 11.4 & 51.1 \\
\hline SD & 1.18 & 4.12 & 2.43 & 11.6 & 15.1 & 18.3 \\
\hline
\end{tabular}

noted that this fraction, along with the $\mathrm{NH}_{4} \mathrm{Cl}$-extractable fraction, are generally considered more bio-available than the other fractions, so the low values for these two fractions suggest very effective biological uptake by plants or bacteria of these forms of $\mathrm{P}$ in Greenfield Lake sediments.

Acid $(\mathrm{HCl})$-extractable $\mathrm{P}$ was relatively more concentrated and much more variable than the more bioavailable $P$ fractions, with an average concentration of $13.7 \mu \mathrm{g} \mathrm{P} \mathrm{g}^{-1}$ sediment and a range of 1.24 to $36.1 \mu \mathrm{g} \mathrm{P}$ $\mathrm{g}^{-1}$ sediment (Table 3 ). Although these values were quite variable among sites, there was no pattern consistent with either sediment characteristics or spatial settings of the sampling sites.

Residual $\mathrm{P}$, defined by this procedure as $\mathrm{P}$ retained in solid form after the four previous extraction procedures but solubilized by digestion with strong sulfuric acid, accounted for approximately one fifth of total P among all samples on average, but was highly variable among samples, averaging $11.4 \mu \mathrm{g} \mathrm{P} \mathrm{g}^{-1}$ sediment, but with a range of 0.05 to $52.9 \mu \mathrm{g} \mathrm{P} \mathrm{g} \mathrm{g}^{-1}$ sediment (Table 3). Despite that variability there was not a clear association between residual $\mathrm{P}$ values and sediment characteristics
(Table 1), nor with location in the lake (Fig. 1), so other variables must have driven residual $\mathrm{P}$ levels.

Humic acid solutions prepared for experimental analyses had absorbances at $490 \mathrm{~nm}$ up to $0.64 \mathrm{AU}$, comparable to the color intensities observed in the original $\mathrm{NaOH}$ extracts of Greenfield Lake sediments. Addition of humic acid solutions to standard solutions of inorganic $\mathrm{P}$ demonstrated interference with both the absorbance of these solutions at $885 \mathrm{~nm}$ and the SRP assay (Table 4). Persulfate digestion eliminated much, but not all, of the color interference caused by humic acid solutions (Table 4), whereas our experiments showed that sulfuric acid eliminated all the humic color interference, perhaps by precipitation of humic acids rather than oxidation of them (Paludan and Jensen 1995). Analysis of humic acid solutions for SRP following digestions with persulfate demonstrated the presence of small but measurable amounts of $\mathrm{P}$ in humic acids themselves (Table 4). Thus, the humic acid materials extracted in the $\mathrm{NaOH}$ step had the potential to interfere with the sequential extraction procedure as originally described in Hupfer et al. (2009).

Table 4. Interactions of humic acids (HA) with persulfate (Pers) digestions (Dig) and soluble reactive phosphate (SRP) analyses. IAbs xxx $_{\text {and }}$ FAbs $_{\mathrm{xxx}}$ are Initial and Final Absorbance values at respective wavelengths; all Absorbance values are means of 3 replicates. DiW = deionized water. Volumes of each reagent per assay are indicated as $\mathrm{ml}$.

Humic acids interfere with SRP assay:

$\mathrm{HA}(2 \mathrm{ml})+\mathrm{DiW}(8 \mathrm{ml})+\mathrm{PO}_{4}(1 \mathrm{ml} \rightarrow 6 \mu \mathrm{M}) \rightarrow \mathrm{SRP} \rightarrow \mathrm{FAbs}_{885}=0.026$

$\mathrm{HA}(8 \mathrm{ml})+\mathrm{DiW}(2 \mathrm{ml})+\mathrm{PO}_{4}(1 \mathrm{ml} \rightarrow 6 \mu \mathrm{M}) \rightarrow \mathrm{SRP} \rightarrow \mathrm{FAbs}_{885}=0.061$

Humic acids contain some $\mathrm{P}$ :

$\mathrm{HA}(1 \mathrm{ml})+\mathrm{DiW}(9 \mathrm{ml})+$ Pers $(1 \mathrm{ml}) \rightarrow \mathrm{IAbs}_{885}=0.001 \rightarrow \mathrm{Dig} \rightarrow \mathrm{SRP} \rightarrow \mathrm{FAbs}_{885}=0.017$

$\mathrm{HA}(2 \mathrm{ml})+\mathrm{DiW}(8 \mathrm{ml})+$ Pers $(1 \mathrm{ml}) \rightarrow \mathrm{IAbs}_{885}=0.003 \rightarrow \mathrm{Dig} \rightarrow \mathrm{SRP} \rightarrow \mathrm{FAbs}_{885}=0.067$

Humic acids are digested only partially by persulfate oxidation:

$\mathrm{HA}(2 \mathrm{ml})+\mathrm{DiW}(8 \mathrm{ml})+$ Pers $(1 \mathrm{ml}) \rightarrow \mathrm{IAbs}_{490}=0.129 \rightarrow \mathrm{Dig} \rightarrow \mathrm{FAbs}_{490}=0.002$

$\mathrm{HA}(8 \mathrm{ml})+\mathrm{DiW}(2 \mathrm{ml})+$ Pers $(1 \mathrm{ml}) \rightarrow \mathrm{IAbs}_{490}=0.515 \rightarrow$ Dig $\rightarrow \mathrm{FAbs}_{490}=0.040$

$\mathrm{HA}(8 \mathrm{ml})+\mathrm{DiW}(1 \mathrm{ml})+$ Pers $(2 \mathrm{ml}) \rightarrow \mathrm{IAbs}_{490}=0.506 \rightarrow \mathrm{Dig} \rightarrow \mathrm{FAbs}_{490}=0.019$ 
Table 5. Total $\mathrm{P}$ levels reported in lake sediments, ug $\mathrm{P}(\mathrm{g} \text { sediment })^{-1}$.

\begin{tabular}{lcl}
\hline \multicolumn{1}{c}{ Lake/Location } & Range/Average & Reference \\
\hline Waccamaw, NC, USA & $4.2-1,158 / 279$ & Cahoon et al. (1990) \\
Søbygaard, Denmark & $<11,300$ & Søndergaard et al. (1993) \\
32 Danish lakes & $200-8,500$ & Søndergaard et al. (1996) \\
Erkin, Sweden & $-/ 1,814$ & Rydin (2000) \\
Dianchi, China & $1,130-3,450$ & Gao et al. (2005) \\
Taihu, China & $420-3,408$ & Jin et al. (2006) \\
Loch Leven, Scotland & $-/ 2,288$ & Spears et al. (2006) \\
Wequaqet, MA, USA & $-/ 1,590$ & Coastal Systems Gp. (2009) \\
Kinneret, Israel & $1,100-1,930$ & Hupfer et al. (2009) \\
Haussee, Germany & $2,000-2,120$ & Hupfer et al. (2009) \\
Kalksee, Germany & $2,650-2,900$ & Hupfer et al. (2009) \\
\hline
\end{tabular}

\section{DISCUSSION}

Total $\mathrm{P}$ values measured in this study were quite low compared to values reported from lakes in other regions (Table 5). Aside from the comparability of sampling and measurement among these other studies, and assuming that these other values are representative, one likely explanation for very low overall $\mathrm{P}$ values in Greenfield Lake is that the extensive vegetation (phytoplankton, filamentous algae, periphyton and macrophytes) throughout the lake's shallow basin recycles nutrients very efficiently and maintains $\mathrm{P}$ in the water column, leaving little to accumulate in sediments. Rooted macrophytes would certainly extract bio-available forms of $\mathrm{P}$ from sediments very efficiently. The very low values observed for the more bio-available $\mathrm{P}$ fractions, $\mathrm{NH}_{4} \mathrm{Cl}$ extractable $\mathrm{P}$ and $\mathrm{NaOH}$-extractable $\mathrm{P}$, support this point. Filamentous algae, periphyton and phytoplankton would rapidly recycle any available $\mathrm{P}$ in the water column. Monitoring studies of Greenfield Lake reported soluble reactive $\mathrm{P}$ levels in the range of $10-90 \mathrm{ug} \mathrm{L}^{-1}$ and total $\mathrm{P}$ levels in the range 10-390 ug $\mathrm{P} \mathrm{L}^{-1}$ (Mallin et al. 2012), rather low values for a eutrophic body of water, and consistent with general uptake and immobilization of soluble P by the lake's biota. The lake's shallow basin would also facilitate sediment suspension in wind storms or flooding events, although the long, narrow main basin of the lake (Fig. 1) and its extensive macrophyte stands would likely limit such physical effects to rare events. Outboard motors $>2.5 \mathrm{hp}$ are prohibited in the lake, so human disturbances are limited. Greenfield Lake has been considered eutrophic, even "hyper-eutrophic," by the NC Dept. of Environment and Natural Resources (NC DENR-DWQ 2005), whereas the other lakes listed in Table 5 are generally considered mesotrophic and certainly are not impacted so extensively by macroflora. Those lakes are also larger and deeper, allowing for more effective accumulation of P-enriched sediment and less effective macrophyte regulation of sediment $P$ levels.

$\mathrm{P}$ concentrations in the $\mathrm{BD}$ (bicarbonate-dithionite) fraction from Greenfield Lake sediments were generally higher than in all other fractions. This fraction primarily includes $\mathrm{P}$ in oxidized, insoluble forms, usually $\mathrm{Fe}$ and Mn complexes that are labile to solubilization in reducing conditions, such as those found in anoxic sediments. The very high plant biomass typical of Greenfield Lake drives diel excursions of dissolved oxygen sufficient to cause nocturnal anoxia and fish kills under certain circumstances (Mallin et al. 2013) and oxygen super-saturation during the day, when our sampling took place, so similarly large oscillations in redox potential are highly likely. Reducing conditions at night and in near-bottom and sediment zones would solubilize the BD-P fraction, making it bio-available to primary producers in the water column and macrophyte roots in the sediments. Although this fraction was relatively highly concentrated in these samples, values for this fraction were much lower in Greenfield Lake than in other lakes (Hupfer et al. 2009), again likely owing to the dominant influence of the lake's biota.

Analysis of the $\mathrm{NaOH}$-extractable $\mathrm{P}$ fraction was rendered more difficult by the presence of significant amounts of humic materials in Greenfield Lake sediments that were not totally digestible with standard persulfate oxidation, interfered with the molybdenumblue assay, but likely contained at least some P. Our modified analysis of this fraction detected low concentrations of $\mathrm{P}$ in this extracted fraction, however, so we conclude that these forms of $\mathrm{P}$ were also not very important in Greenfield Lake sediments, partly owing to reducing conditions in the sediments that would limit formation of $\mathrm{NaOH}$-extractable metal hydroxides, oxyhydroxides, and hydroxyl-phosphates in preference to metal sulfides, perhaps owing to low $\mathrm{P}$ content of the otherwise abundant humic materials in this lake, and likely also owing to rapid biotic uptake of these relatively bioavailable $\mathrm{P}$ forms (Fytianos and Kotzakiota 2005; Zhou et al. 2001). Finally, pH excursions to values as high as 10 have been observed in Greenfield Lake owing to high photosynthetic rates, so $\mathrm{pH}$ may often have been high enough to solubilize some of this $\mathrm{P}$ fraction and facilitate biotic uptake (Chrystophoridis and Fytianos 2006). 
We note that published analyses of sediment $\mathrm{P}$ fractions in other lakes (Table 5) do not mention specific concerns with humic materials. Analyses of the interaction between humics and phosphate in lacustrine settings similar to that of Greenfield Lake have found evidence that phosphate can form chemical complexes with humic compounds (Paludan and Jensen 1995). On one hand a small, urbanized watershed like that of Greenfield Lake may contribute an inordinately large proportion of allochthonous organic matter and humic materials in comparison to larger lakes with dominating terrestrial influences limited to narrow littoral zones. Observations of the dark brown color of the water column in Greenfield Lake, with leaf litter throughout its basin, support this view. The lake itself hosts extensive stands of cypress trees and other deciduous, wetland species, e.g., sweet gum, that contribute organic matter by leaching and leaf accumulation. Many larger, deeper lakes may have relatively smaller contributions from humic material, particularly in central basin sediments. Thus, interferences by humic materials may be less problematic for sediment $\mathrm{P}$ extraction and analysis in those settings.

The HCl-extractable $\mathrm{P}$ fraction was also relatively concentrated in Greenfield Lake sediments, averaging 13.7 ( $\mathrm{SD} \pm 11.4)$ ug $\mathrm{P} \mathrm{g}^{-1}$ sediment. Most of this fraction is composed of authigenic calcium phosphorus compounds that derive from co-loading of calcium compounds leached from coastal soils in this region, liming of residential yards, and leaching of concrete in addition to phosphorus fluxes in the watershed. This fraction is often considered as relatively unavailable to biota, owing to the need for very low $\mathrm{pH}$ to dissolve it (Driscoll et al. 1993; Penn et al. 2000; Jin et al. 2006), but research has shown that some biota can extract $\mathrm{P}$ from authigenic calcium compounds using organic acids that complex solubilized calcium (Gill 2006). Concentrations of this P fraction in Greenfield Lake were very low in comparison to other calcium-rich lakes with very high quantities of $\mathrm{HCl}$-extractable, authigenic $\mathrm{P}$ (Hupfer et al. 2009; Table 5). This difference suggests the possible importance of biota in this shallow, eutrophic in sequestering $\mathrm{P}$ before authigenic $\mathrm{P}$ formation could proceed and/or mobilizing $\mathrm{P}$ fractions often considered unavailable, and that attempts at sequestration of $\mathrm{P}$ by interaction with calcium, i.e., liming the lake, would likely fail.

Residual P, which is usually considered to be a mix of refractory organic compounds and inorganic minerals, was also relatively more concentrated, although more variably so, than the bio-available $\mathrm{P}$ fractions in Greenfield Lake sediments, but quite low in comparison to values from other lakes (Hupfer et al. 2009). Low values for this fraction, with none exceeding $52.9 \mathrm{ug} \mathrm{P} \mathrm{g-}$ 1 sediment, at site 3 in a tributary (Fig. 1), suggest another explanation for low overall P levels in Greenfield Lake sediments - dredging may have been very effective in removing accumulated P. No measurements of the $\mathrm{P}$ content of dredged sediments are available, thus it is difficult to test that proposition, but low concentrations of residual $\mathrm{P}$ in lake sediments are difficult to reconcile with any other explanation.

Our results strongly indicate that the role of the biota in sequestering and recycling $\mathrm{P}$ should not be underestimated in eutrophic, shallow lakes. Analysis of the P content of aquatic flora would be a useful test of the hypothesis that biotic sequestration is more important than the sediment $\mathrm{P}$ reservoir in this situation. This proposal is complicated, however, by lack of standard methods for quantifying the areal biomass of aquatic macrophytes, their epiphytes and filamentous algae. Nevertheless, efforts to remediate the eutrophic character of Greenfield Lake and lakes like it might benefit from macrophyte removal campaigns, bearing in mind the ecological importance of maintaining limited populations of macrophytes.

Acknowledgments: We thank the UNC Wilmington Honors College and Ann Sherman Skiba for helping to fund this research through an Undergraduate Fellowship to M.D. Roman. Additionally, thanks go to Scott Whitham, the Greenfield Lake Manager for the Cape Fear River Watch, for providing a motor boat and a kayak to use on Greenfield Lake for sampling, and to Kevin Blackburn, who helped collect samples on the first sampling trip. Finally, we thank an anonymous reviewer and the editor for helpful comments on the manuscript.

\section{LITERATURE CITED}

ALDOUS, A. R., C. B. CRAFT, C. J. STEVENS, M. J. BARRY, AND L. B. BACH. 2007. Soil phosphorus release from a restoration wetland, Upper Klamath Lake, Oregon. Wetlands 27:10251035.

CAHOON, L. B., J. R. KUCKLICK, AND J. C. STAGER. 1990. A natural phosphate source for Lake Waccamaw, North Carolina. Int. Rev. ges. Hydrobiol. 75:339-351.

CHRISTOPHORIDIS, C., AND K. FYTIANOS. 2006. Conditions affecting the release of phosphorus from surface lake sediments. Journal of Environment Quality 35:1181.

COASTAL SYSTEMS GP. 2009. Lake Wequaquet Water Quality Assessment, Final Report. Coastal Systems Group, School of Marine Science and Technology, University of Massachusetts Dartmouth, 706 South Rodney French Blvd., New Bedford, MA 02744-1221. $68 \mathrm{p}$.

DRISCOLL, C. T., S. W. EFFLER, M. T. AUER, S. M. DOERR, AND M. R. PENN. 1993. Supply of phosphorus to the water column of a productive hardwater lake: controlling mechanisms and management considerations. Hydrobiol. 253:61-72.

FYTIANOS, K., AND A. KOTZAKIOTI. 2005. Sequential fractionation of phosphorus in lake sediments of Northern Greece. Env. Mon. Assess. 100:191-200.

GILL, S. 2006. Phosphorus liberation by aquatic microrganisms. Unpublished M.S. thesis, U.N.C. Wilmington, 66 p. 
HECKY, R. E., AND P. KILHAM. 1988. Nutrient limitation of phytoplankton in freshwater and marine environments: a review of recent evidence. Limnol. Oceanogr. 33:796-822.

HUPFER, M., D. ZAK, R. ROBBERG, C. HERZOG, AND R. PÖTHIG. 2009. Evaluation of a well-established sequential phosphorus fractionation technique for use in calcite-rich lake sediments: identification and prevention of artifacts due to apatite formation. Limnol. Oceanogr.: Methods 7:399-410.

JIN, X., S. WANG, Y. PANG, AND F. CHANG WU. 2006. Phosphorus fractions and the effect of $\mathrm{pH}$ on the phosphorus release of the sediments from different trophic areas in Taihu Lake, China. Env. Poll. 139:288-295.

MALLIN, M. A., E. A. STEFFY, M. R. MCIVER, AND E. CLAY. 2012. Environmental quality of Wilmington and New Hanover County watersheds, 2011. UNCW Center Marine Sci. Rep. 12-01, 83 p.

MALLIN, M. A., L. E. BOHRER, M. R. MCIVER, S. PROTOPAPPAS. 2013. Environmental Quality of Wilmington and New Hanover County Watersheds, 2013. UNCW Center Marine Sci. Rep. 13-01, 84 p.

NC DENR-DWQ. 2005. Cape Fear basinwide water quality plan. N. C. Dept. Environ. Nat. Res.-Div. Water Quality, Raleigh, NC. 332 p.

PALUDAN, C., AND H. S. JENSEN. 1995. Sequential extraction of phosphorus in freshwater wetland and lake sediment: significance of humic acids. Wetlands 15:365-373.

PARSONS, T. R., Y. MAITA, AND C. M. LALLI. 1984. A Manual of Chemical and Biological Methods for Seawater Analysis. Pergamon Press, London. 173 p.

PENN, M. R., M. T. AUER, S. M. DOERR, C. T. DRISCOLL, C. M. BROOKS, AND S. W. EFFLER. 2000. Seasonality in phosphorus release rates from the sediments of a hypereutrophic lake under a matrix of $\mathrm{pH}$ and redox conditions. Can. J. Fish. Aq. Sci. 57:1033-1041.
PETTERSSON, K., B. BOSTRÖM, AND O.-S. JACOBSEN. 1988. Phosphorus in sediments-speciation and analysis. Hydrobiol. 170:91-101.

PSENNER, R., R. PUCSKO, AND M. SAGER. 1984. Die Fraktionierung organischer und anorganischer Phosphorverbindungen von Desimenten: verush einer Definition ökologisch wichtiger Fraktionen. Arch. für Hydrobiol. 70:111-155.

RYDIN, E. 2000. Potentially mobile phosphorus in Lake Erkin sediment. Water Res. 34:2037-2042.

SØNDERGAARD, M., R. BJERRING, AND E. JEPPESEN. 2013. Persistent internal phosphorus loading during summer in shallow eutrophic lakes. Hydrobiol. 710:95-107.

SØNDERGAARD, M., J. P. JENSEN, AND E. JEPPESEN. 2003. Role of sediment and internal loading of phosphorus in shallow lakes. Hydrobiol. 506-509:135-145.

SØNDERGAARD, M., P. KRISTENSEN, AND E. JEPPESEN. 1993. Eight years of internal phosphorus loading and changes in the sediment phosphorus profile of Lake Søbygaard, Denmark. Hydrobiol. 253:345-356.

SPEARS, B., L. CARVALHO, R. PERKINS, A. KIRIKA, AND D. PATERSON. 2007. Sediment phosphorus cycling in a large shallow lake: spatio-temporal variation in phosphorus pools and release. Hydrobiol. 584:37-48.

VALDERRAMA, J. G. 1981. The simultaneous analysis of total nitrogen and phosphorus in natural waters. Mar. Chem. 10:109-122.

ZHANG, X., Z. LIU, R. D. GULATI, AND E. JEPPESEN. 2013. The effect of benthic algae on phosphorus exchange between sediment and overlying water in shallow lakes: a microcosm study using ${ }^{32} \mathrm{P}$ as a tracer. Hydrobiol. 710:109-116.

ZHOU, Q., C. E. GIBSON, AND Y. ZHU. 2001. Evaluation of phosphorus bioavailability in sediments of three contrasting lakes in China and the U.K. Chemosphere 42:221-225. 